\title{
Geography and history matter: International business and economic geography perspectives on the spatial and historical development of multinational enterprises
} DOI:

10.1057/9781137473110.0010

Link to publication record in Manchester Research Explorer

Citation for published version (APA):

Johns, J., Buckley, P., Campling, L., Cook, G., Hess, M., Sinkovics, R. R., Konara, P. (Ed.), Ha, Y. J. (Ed.), McDonald, F. (Ed.), \& Wei, Y. (Ed.) (2015). Geography and history matter: International business and economic geography perspectives on the spatial and historical development of multinational enterprises. In The rise of multinationals from emerging economies: achieving a new balance (Vol. 22, pp. 51-80). (Academy of International Business (UKI) Series). Palgrave Macmillan Ltd. https://doi.org/10.1057/9781137473110.0010

Published in:

The rise of multinationals from emerging economies: achieving a new balance

\section{Citing this paper}

Please note that where the full-text provided on Manchester Research Explorer is the Author Accepted Manuscript or Proof version this may differ from the final Published version. If citing, it is advised that you check and use the publisher's definitive version.

\section{General rights}

Copyright and moral rights for the publications made accessible in the Research Explorer are retained by the authors and/or other copyright owners and it is a condition of accessing publications that users recognise and abide by the legal requirements associated with these rights.

Takedown policy

If you believe that this document breaches copyright please refer to the University of Manchester's Takedown Procedures [http://man.ac.uk/04Y6Bo] or contact uml.scholarlycommunications@manchester.ac.uk providing relevant details, so we can investigate your claim.

\section{OPEN ACCESS}


Johns, Jennifer, Peter Buckley, Liam Campling, Gary Cook, Martin Hess, and Rudolf R. Sinkovics (2015), "Geography and history matter: International business and economic geography perspectives on the spatial and historical development of multinational enterprises," in The rise of multinationals from emerging economies: Achieving a new balance, Palitha Konara, Yoo Jung Ha, Frank McDonald, and Yingqi Wei (Eds.). Academy of international business (uki) series Vol. 22. Houndmills, Basingstoke, Hampshire, U.K.: Palgrave Macmillan, 51-80. (DOI: 10.1057/9781137473110.0010).

\section{Geography and History Matter: International Business and Economic Geography Perspectives on the Spatial and Historical Development of Multinational Enterprises}

Jennifer Johns, Peter Buckley, Liam Campling, Gary Cook, Martin Hess, and Rudolf R. Sinkovics

Situated within the broader conference theme of historical change, this panel session brought together international business and economic geography perspectives on multinational enterprise (MNE) evolutionary trajectories. The panel session follows a series of past conference sessions aimed to increase dialogue and interaction between economic geographers and international business scholars. These included several sessions at the Royal Geographical Society and Institute of Geographer's Annual Conference in 2010 and the Association of International Business in 2012. The aim for this conference panel session was for panellists to offer a range of empirical and conceptual observations to interrogate our existing understandings of the spatial and historical development of MNEs. While space and time often provide distinct lenses on the operations of MNEs, the panel discussed the ways in which the two can be combined to provide more nuanced conceptualisations and frameworks for analysis, which can powerfully complement existing conceptual frameworks and methodological approaches in international business. This chapter is a record of the panel session and, as such, offers a direct representation of the speakers' presentations, their discussions and their question and answer session. The chapter begins with Martin Hess' discussion of continuity and change in MNEs and global production networks, followed by Rudolf Sinkovics' analysis of the uptake of economic geography work on global sourcing by international business. Liam Campling then introduces us to commodity chains 
and commodity frontiers before Peter Buckley offers a summary and discussion of the key debates and issues raised. The chapter includes the questions posed to the panel and the answers and discussion offered in response.

\section{Continuity and change: MNE and global production networks (GPN), by Martin Hess}

Continuity and change with regard to MNEs and GPNs is something I have been working on for the last ten years with colleagues. I hope this will be useful as we look at the evolution of multinational enterprises in a world of fragmented value chains and the new geographies of MNEs that we see emerging especially in the Global South and as we look at what this means for the challenges facing international business and economic geography. I would argue the challenge is to explain the spatial and temporal fix of capital in contemporary capitalism.

Just as a quick reminder, and it will be brief as it is very familiar, MNEs are obviously still very important in the world economy, and according to statistics from UNCTAD (2011), there were 37,000 in the 1990s, and this has gone to a population of more than 100,000 MNEs in 2010. There was also a shift in where these parent companies originate. In the early 1990s, 90 per cent originated from the developed world, and this has gone down to 70 per cent (UNCTAD, 2011). So there has been an increase in MNEs originating from developing economies and emerging markets.

What I want to argue is that this is only part of the wider picture. Firms are part of wider global production networks. Global production networks, as we define them in economic geography, describe the nexus of interconnected functions and operations through which goods and services are produced and also distributed and consumed. These GPNS over the last decades have become both organisationally much more complex but also increasingly global in their reach and extent. What these networks do: they not only integrate firms and parts within firms into structures that tend to blur traditional organisational boundaries but also integrate national economies and parts of such economies in various ways that have enormous implications for the well-being and development of places. In a nut shell, they cut through state boundaries in various differentiated ways, and this is influenced in part by regulatory and non-regulatory barriers but also, and importantly, social and cultural conditions which create structures which are discontinuously territorial. This is important in the context of economic geography and international business dialogue because this goes way beyond methodological nationalism which often we find in both disciplines. It emphasises that place, rather than just the nation-state boundary, matters for MNEs and the GPNS they connect. What we want to do, within this GPN approach, is to understand the social and developmental dynamics of contemporary capitalism at the global-local nexus across different scales. This is an approach developed mostly within economic geography, and 
it is a development of a large project we worked on. What this GPN heuristic framework does is operate though three analytical lenses or registers. I'm not going into detail here; I just want to use these three analytical categories as a structuring element for the next few pointers.

So, GPNs look at processes of value creation, enhancement and, importantly, who captures value in these value production systems; the related governance and power structure - power as corporate power, exercised by firms, but also non-firm institutions, and ultimately it looks at global production networks and multinationals as embedded organisations, embedded in particular territories and places, but also creating embedded networks and embedded in society. I want to mobilise these three registers and think a little bit about them in relation to recent trends in MNE and GPN development.

Basically, the classic focus maybe of international business, if I can simplify, is mostly on the firm and maybe also on some sectors created by these firms. Whereas traditionally economic geography has focused more on territorial development and often left the firm as a black box. At the end I will argue that there is a fruitful interface for both our disciplines to explore. OK. Let me start with the first of these registers - value generation and capture. Again, I can address only one or two issues that I think are interesting and might be important for our discussion.

Over the last decade, we have seen quite a substantial process of financialisation, of changing sources and uses of profit by multinational enterprises, driven by financial markets and by shareholder capitalism. As a consequence, we have evermore finely sliced value chains emerging in many sectors. So FDI

\begin{tabular}{|c|c|c|c|}
\hline Categories & $\begin{array}{l}\text { Value } \\
\text { - Creations } \\
\text { - Enhancement } \\
\text { - Capture }\end{array}$ & $\begin{array}{l}\text { Power } \\
\text { - Corporate } \\
\text { - Collective } \\
\text { - Institutional }\end{array}$ & $\begin{array}{l}\text { Embeddedness } \\
\text { - Territorial } \\
\text { - Network }\end{array}$ \\
\hline Dimensions & $\stackrel{\downarrow}{\downarrow}$ & & $\begin{array}{c}\downarrow \\
\text { Structures }\end{array}$ \\
\hline \multirow{2}{*}{\multicolumn{2}{|c|}{$\begin{array}{l}\text { Firms } \\
\text { - Ownership } \\
\text { - "Architecture" } \\
\text { Institutions } \\
\text { - Governmental } \\
\text { - Quasi-govermental } \\
\text { - Non-govermental }\end{array}$}} & \rfloor$_{\downarrow}^{\text {iguration }} \underset{\text { dination }}{\longleftarrow}$ & \multirow[t]{2}{*}{$\begin{array}{l}\text { Networks (Business/Political) } \\
\text { - "Architecture" } \\
\text { - Power configuration } \\
\text { - Governance } \\
\text { Sectors } \\
\text { - Technologies } \\
\text { - Products/Markets }\end{array}$} \\
\hline & & lopment & \\
\hline
\end{tabular}

Figure 3.1 A framework for global value chain analysis Source: Henderson et al. (2002: Figure 1). 
is still important, but there are many other forms now, in terms of subcontracting and task segmentation in these systems. This slicing of the value chain has created new geographies of outsourcing and offshoring to keep costs down. This is a prerequisite for many firms in the process of financialisation. As a result, we also have seen, over the last couple of decades or so, a change in multinational enterprises towards fabless firms - a lot of companies that don't produce anymore but rather rely on brand-rents. One example for that - a very famous example - is Apple (See Figure 3.2).

Apple doesn't produce anything at all - at least it didn't until very recently when it brought back a production facility to the United States - but this is a classic example of a company relying on financialisation as a business strategy. As you can see (in Figure 3.2), brand-rents play an important part here. The gross margin for Apple is about 70 per cent of the whole production system. How an Apple 4G phone is produced involves multiple geographies, multiple global production networks. Each of these components creates GPNs in its own right and is often driven by multinational enterprises. Assembly takes place in China, which makes up only a small part of this whole system. Foxconn, the Taiwanese multinational, produces the Apple iPhone in various places in China and, unlike Apple, captures a lot of the value through this model. Foxconn has 70 per cent labour share of the value added. A very different kind of setting for this MNE, and the value-added to sales ratio for Foxcomm in this system is only 12 per cent. So that has certain implications for MNE strategy for companies like Foxconn.

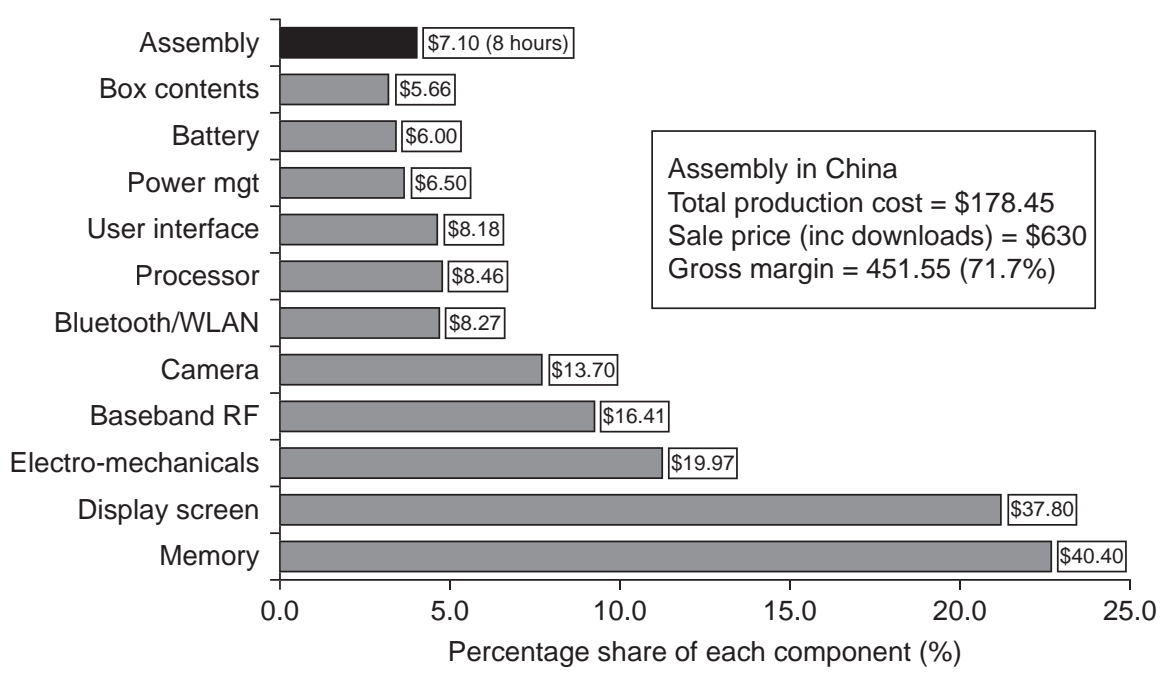

Figure 3.2 Share of production cost of an Apple 4G iPhone assembled in China Notes: Excludes software, licensing, royalties.

Source: Froud et al. (2012: Figure 5). 
The second register, and I guess this will feature more prominently throughout our discussion, features questions around power and governance in MNEs and their wider global production networks. I would argue that MNEs have become over time more and more 'networks within networks'. They have often become temporary coalitions of activities and value-added activities that break up and reassemble in new configurations to the boundaries of the firm. They have always been to some extent blurred but have become arguably more blurred over the last few years. So there arise questions about changing forms of governance of these wider production and value-added systems within and beyond firms. It also arguably creates some kinds of new breeds of multinational enterprises. Again, I want to use just a brief example to illustrate this. The global garment manufacturing industry has been discussed for a long time under the new international division of labour model, but there are companies now emerging that have very new and different characteristics. Li and Fung from Hong Kong is a classic example of that. Again, it is an intermediary company, a logistics company. It orchestrates 15,000 or so suppliers across a huge number of countries. It doesn't own a single one of them. It doesn't own any production facilities. It is a multinational enterprise, yes, because it has offices in 40 countries, but there is little foreign direct investment involved. The rationale of the OLI paradigm and FDI is much less relevant here given what they do in terms of orchestrating these massive production systems. They also apply particular strategies to divide and conquer these vast networks. What they try to achieve is ensuring that the lead supplier has at least 30 per cent of their capacity but no more than 70 per cent of the factory output in order to have enough share to be influential and important for the supplier, but not to be too dominant and be the single buyer from these suppliers. So it is a very intriguing strategy. They also increasingly try to branch out into the upper end of the value chain, into retail. They have their own brand, Fishman and Tobin, and they orchestrate supply chains for large multinationals like Walmart. Walmart is said to be potentially the eighth or ninth largest trade partner with China, if it were a country, so it is massive. Li and Fung moves into this system and orchestrates around 200 billion dollars' worth of sourcing for Walmart and operates all the global sourcing and US distribution of the brand Liz Claiborne.

Finally, the third register is the analytical category of embeddedness. In economic geography, I think the fundamental thing that we look into is the social-cultural context, and geographical context matters. It is about the territorial embeddedness of multinationals as well as the wider GPNs they connect. It also matters, of course, where MNEs come from, and that echoes discussions in the literature on national business systems, like Richard Whitley's work, but also the varieties of capitalism literature that came out as part of institutional economics. So, firms are embedded in particular territories, in particular wider networks and societies. Retail is a good example. Retail internationalisation is a phenomenon that took place over only the last 10-20 years really and wasn't 
discussed before that. It clearly emphasises the importance of the socio-political and cultural context as companies like Tesco expanded and also retracted, retreating from California, for instance, which is in part to do with the misunderstanding of the frameworks within which they operate - the institutional and regulatory frameworks in the particular countries, but also arguably more importantly, consumer culture and the societies into which they expanded. At the same time, it is not only about expanding their sales floor space into countries, but also about orchestrating a huge number of suppliers across the globe and hence have a dual influence in this regard.

Just to wrap-up, based on these brief pointers, bringing international business studies and economic geography together is an intriguing prospect, and coming back to issues around global production networks, the strategic coupling process between global production networks which are made up of focus firms, multinationals, but also their subsidiaries and suppliers, the strength of international business research, how this couples with regional assets in terms of technology, organisation and territory, that could be an interface that could be useful to explore further in an economic geography/ international business dialogue.

\section{Global value chains (GVCS), global production networks (GPN) and international business (IB), by Rudolf R. Sinkovics}

The presentation title is 'Global value chains, global production networks and international business', and I believe the invitation is a function of my involvement in an ESRC project dealing with firms from 'Rising Powers', which are increasingly taking on critical roles in GPNs and GVCs. This an interdisciplinary project where I am looking particularly at the firm aspect, while my colleagues in other departments in Manchester are looking at other dimensional outcomes - for example, labour, social responsibility issues. For me, when I first got involved in this network around 2010, it was a very significant, steep learning curve which I don't think I have quite completed as yet. What you will experience here is some of my own thinking around what has happened in the literature around GVCs and GPNs, which at some stage in their history became separated from what was originally, I would argue, an IB topic or a topic very much at the core of IB. So, we are working in an interdisciplinary context in this research project, and I wanted to look at the drivers and outcomes of emerging power and the players - not only firms but also state actors, governments, NGOs and so on - in the context of what is called 'rising power' countries, if using the Economic and Social Research Council (ESRC) terminology, otherwise also called the BRIC countries

In my presentation I essentially offer a bibliographic analysis, starting my search on the notion of 'value chain' within the domain of IB. Interestingly, there is a paper by Kogut (1985) that carries 'value chains' in the title, but after 
this 1985 paper, there was no single IB paper for quite some time that actually utilised the term in a similar way to how it is used in the sense of GVCs, in the more sociologically inspired literature, or how it is picked up and used by economic geographers. I would argue that, with the emergence of the resourcebased view, there is less consideration of the orchestration and structuring of the value chain in the original Porterian way. It has fallen out of use in the literature. I proceed by exploring what the global value chain is, and when it was that GVCs as a term re-entered the landscape of IB. When was it taken up again? Is there a take up? If so, how is this being done? Ultimately, what I want to look at is which dimensions are being used very prominently in the GPN and GVC literature, but not in IB. I would like to finish with a question mark around the degree to which IB scholars can learn from this literature and - if useful - perhaps implement some of the concepts in their own work.

In the first step, I utilise the Social Sciences Citation Index (SSCI) database and look at the corpus of GVC research. The analysis that I am presenting is also narrowed down by the ability to scroll through the literature in SSCI, but what you see here is that I was looking comprehensively and very broadly around the issues of GVCs and GPNs, confined to all the articles published between 1970 and

\begin{tabular}{|c|c|c|c|}
\hline Field: Authors & Record count & $\begin{array}{c}\text { percentage } \\
\text { of } 549\end{array}$ & Bar chart \\
\hline NADVI K & 10 & $1.821 \%$ & I \\
\hline BARRIENTOS S & 8 & $1.457 \%$ & I \\
\hline COE NM & 8 & $1.457 \%$ & I \\
\hline GEREFFI G & 8 & $1.457 \%$ & I \\
\hline WEI YHD & 8 & $1.457 \%$ & I \\
\hline FRANZ M & 7 & $1.275 \%$ & I \\
\hline PONTE S & 7 & $1.275 \%$ & I \\
\hline YEUNG HWC & 7 & $1.275 \%$ & I \\
\hline HESS M & 6 & $1.093 \%$ & I \\
\hline GRIMES S & 5 & $0.911 \%$ & I \\
\hline HASSLER M & 5 & $0.911 \%$ & I \\
\hline PAVLINEK P & 5 & $0.911 \%$ & I \\
\hline PICKLES J & 5 & $0.911 \%$ & 1 \\
\hline RABELLOTTI R & 5 & $0.911 \%$ & I \\
\hline RIISGAARD L & 5 & $0.911 \%$ & I \\
\hline Field: Authors & Record count & $\begin{array}{c}\text { percentage } \\
\text { of } 549\end{array}$ & Bar chart \\
\hline
\end{tabular}

Figure 3.3 Authors in the GVC/GPN domain 
2014. A total of 549 papers came to light that had, in their abstract or title, some notion of GNCs or GPNs. When we look at the authors in this domain that are possibly being used and cited in IB, then we see quite an interesting ranking (3).

We see Khalid Nadvi, who is the lead author on this ESRC grant in Manchester; Stefanie Barrientos, at Manchester; Neil Coe who previously was in Manchester, now Singapore; Gary Gereffi, Duke University; and further down we have Henry Yeung and Martin Hess. Moving on beyond authors, I further looked at the papers and the titles, abstracts, and key words that gave any indication of GVCs or GPNs. If you look further down in terms of disciplinary utilisation of these 549 papers that we have here, where do they occur? Quite rightly, most of the members of this panel are economic geographers because most of the work is coming out of geography (232 papers) (see Figure 3.4). In total, there are 75 IB papers that either cite a GVC/GPN paper (as defined earlier) or mention the term GVC/GNP. There are three papers that mention the term but don't cite any of the GVC/GNP literature. There are some strategic citations in there as

\begin{tabular}{|c|c|c|c|}
\hline Field: Web of science categories & Record count & $\begin{array}{c}\text { percentage } \\
\text { of } 549\end{array}$ & Bar chart \\
\hline GEOGRAPHY & 232 & $42.259 \%$ & $\square$ \\
\hline ECONOMICS & 175 & $31.876 \%$ & 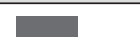 \\
\hline PLANNING DEVELOPMENT & 120 & $21.858 \%$ & 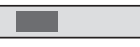 \\
\hline ENVIRONMENTAL STUDIES & . . . . . . . & ـ & ........ \\
\hline MANAGEMENT & 62 & $11.293 \%$ & $\square$ \\
\hline ( & $50 . \ldots$ & _. & A......... \\
\hline SOCIOLOGY & 45 & $8.197 \%$ & 口 \\
\hline URBAN STUDIES & 37 & $6.740 \%$ & 口 \\
\hline AREA STUDIES & 27 & $4.918 \%$ & $\square$ \\
\hline POLITICAL SCIENCE & 21 & $3.825 \%$ & I \\
\hline ANTHROPOLOGY & 18 & $3.279 \%$ & I \\
\hline INTERNATIONAL RELATIONS & 18 & $3.279 \%$ & I \\
\hline ENVIRONMENTAL SCIENCES & 11 & $2.004 \%$ & I \\
\hline INDUSTRIAL RELATIONS LABOR & 11 & $2.004 \%$ & I \\
\hline OPERATIONS RESEARCH MANAGEMENT SCIENCE & 11 & $2.004 \%$ & I \\
\hline ETHICS & 8 & $1.457 \%$ & I \\
\hline GEOGRAPHY PHYSICAL & 8 & $1.457 \%$ & I \\
\hline AGRICULTURE MULTIDISCIPLINARY & 7 & $1.275 \%$ & I \\
\hline SOCIAL SCIENCES INTERDISCIPLINARY & 7 & $1.275 \%$ & $\mathrm{I}$ \\
\hline TRANSPORATION & 7 & $1.275 \%$ & I \\
\hline ENGINEERING INDUSTRIAL & 6 & $1.093 \%$ & I \\
\hline HISTORY PHILOSOPHY OF SCIENCE & 6 & $1.093 \%$ & I \\
\hline AGRICULTURAL ECONOMICS POLICY & 5 & $0.911 \%$ & I \\
\hline LAW & 5 & $0.911 \%$ & I \\
\hline
\end{tabular}

Figure 3.4 Web of Science categories and published work 
well. What I am trying to allude to here is, yes, the business and management literature is becoming more conscious of its origins. The Porterian value chain has been fed into the GVC discussion around Gereffi and other people, and recent publications over the last ten years are looking at issues like governance and notions of power, which have some interesting connotations for the agenda of IB. So, in a sense, there is increasing recognition of these topics within IB.

For further background, England is quite prominent in the origins of the papers (130 papers compared to 134 coming from the US). This is comforting from an AIB-UKI perspective as it is very closely behind the US in terms of the authors. Again, pleasing from the University of Manchester's point of view, we are apparently ranked number 1 in this particular analysis with respect to contributions to the topic of GVCs/GPNs. The 549 papers in the sample that carry GVC/GPN in their title and abstracts, have been cited 6,261 times. Around 2,000 citations would be self-citations, but there are more than 3,500 genuine citations, signifying the impact of these articles. The Hirsch index, an indication of the impact of these papers over time, is also quite significant, at 34. What is nice to see here is that, on the whole, the literature on GPNs and GVCs has taken off quite significantly over the last decade - in the specialist areas of economic geography and development studies, and before that there were some notable publications. But over the last few years the citations have increased substantially.

The next figure is a 3D diagram (Figure 3.5), illustrating how IB has taken up this topic.

The Gereffi, Humphrey and Sturgeon (2005) paper on the governance of GVCs in the Review of International Political Economy is the one that has been most widely utilised. In terms of IB citations it leads the crowd, with 16 papers utilising this particular contribution. If we go through the figure, we can see that Henderson et al. (2002) has been cited only once. The work by Humphrey and Schmitz (2002), who also showcased some of their work at the recent EIBA (European International Business Association) conference in Sussex, has been cited five times. We can see that Giuliani, Pietrobelli and Rabellotti (2005) on upgrading in GVCs has received some attention in $\mathrm{IB}$, which is indicative of the fact that the notion of upgrading can be useful in the firm context. I believe Martin Hess is hidden in this chart somewhere as well, which in a way indicates how the work of economic geographers is frequently overlooked in IB. So, what you see here is that the zero citations are mostly coming from authors with an economic geography background.

In the next step I was interested in which concepts are most widely used in the most cited GVC papers. I extracted the most widely cited GVC/GPN papers here and examined their density to identify 'hot' and 'cold' terms. The hot zones are basically GVCs and, on the other side, GPNs, so there are two strands of literature. I guess Martin Hess would be exhibiting the GPN perspective. 


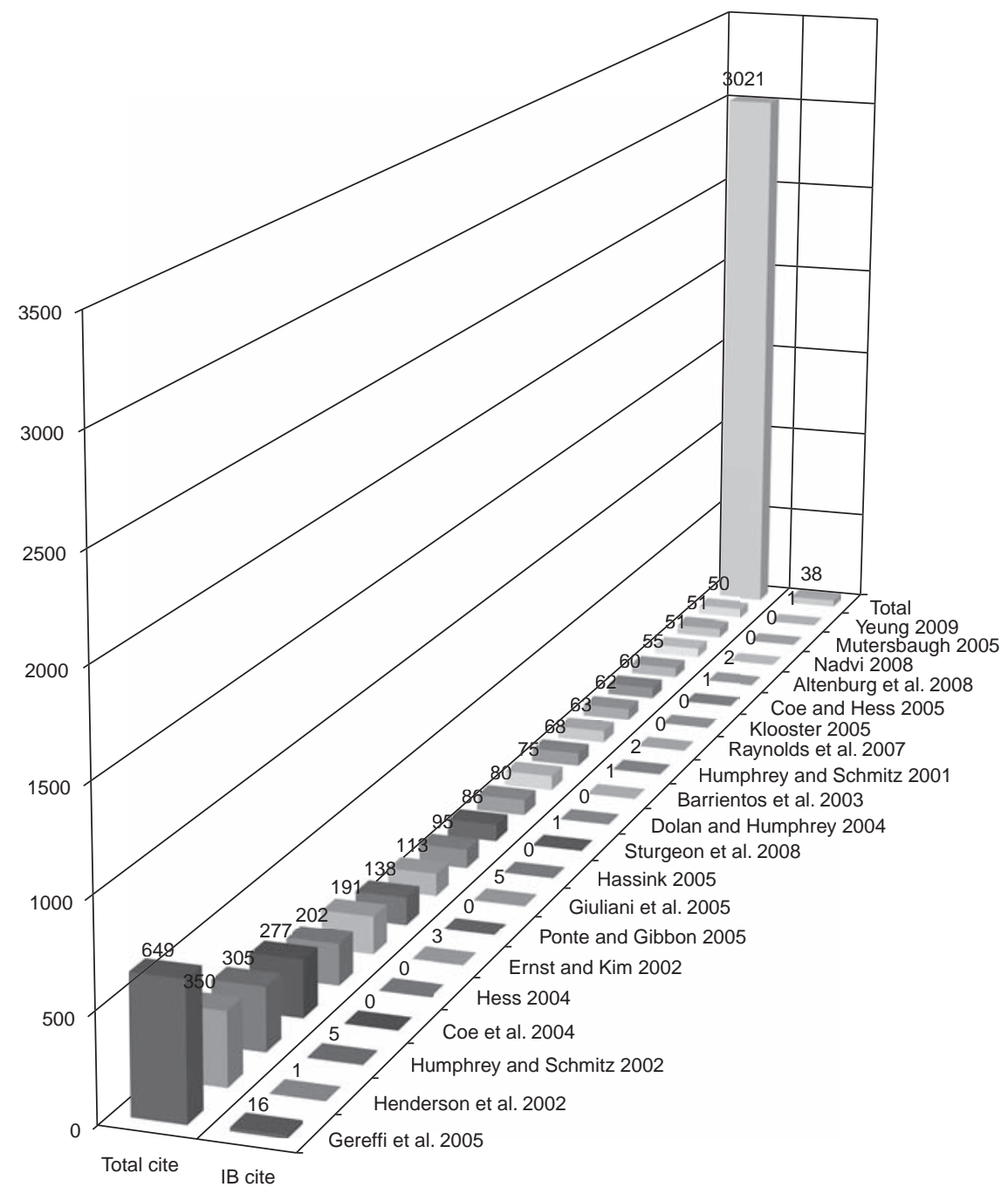

Figure 3.5 Twenty most cited GVC articles (out of 549)

And there are other people representing the GVC perspective, interested in the governance of firms, and issues such as the role of institutional actors. I also analyse the data using a cluster-density view, which - building on the most widely cited themes - in these literatures. In the 20 most cited papers, there is a red area which is GPNs, about upgrading, about implications for development, and then we have a green cluster around capabilities in terms of how deeply tacit knowledge is being absorbed - for instance, how much innovation is taking place. The central node is GVCs, and there we also have a lot of work 
using and drawing on the GVC literature related to issues of standards. So this is looking at the governance of production networks, including considerations of product and labour standards.

The next step before I conclude is to ask, really, where is it that the 20 most cited publications are used in IB? Here we see a shrinking of the space of IB, towards four or five papers, from the Journal of International Business Studies, the International Business Review, the Journal of International Management, the Journal of World Business and the Management International Review. You can see which types of papers are used most widely in which journal. There has been, interestingly enough, in JIBS recently, an increasing awareness of GVCs/GPNs, largely in the work of Ram Mudambi and the special issue around economic geography (Beugelsdijk and Mudambi 2013), so there are a couple of citations. This goes back to the sources which are really the foundational papers around GVC and GPN. There is an increasing level of awareness in IBR, but the rest of the journals are receiving fewer citations, or the authors who are publishing in them are not necessarily drawing that frequently on GVC/GPN papers.

So, in which context are these 20 most cited GVC/GPN papers used in IB? Mostly it is when we are talking about firm strategy. I use a term density map so, mostly, any type of GVC/GPN work that has implications for firms, or firms' strategic development, issues of improvements on certain strategic issues, such as in BRIC countries, these would be the central themes. The density view shows us the number of clusters in this context (Figure 3.6). Very briefly, I am not yet completely done with this study. I was only just getting started when I received the invitation to speak here, so I am not really fully finished with it and this is kind of an exploratory look so far. But now I go into a thematic analysis, looking

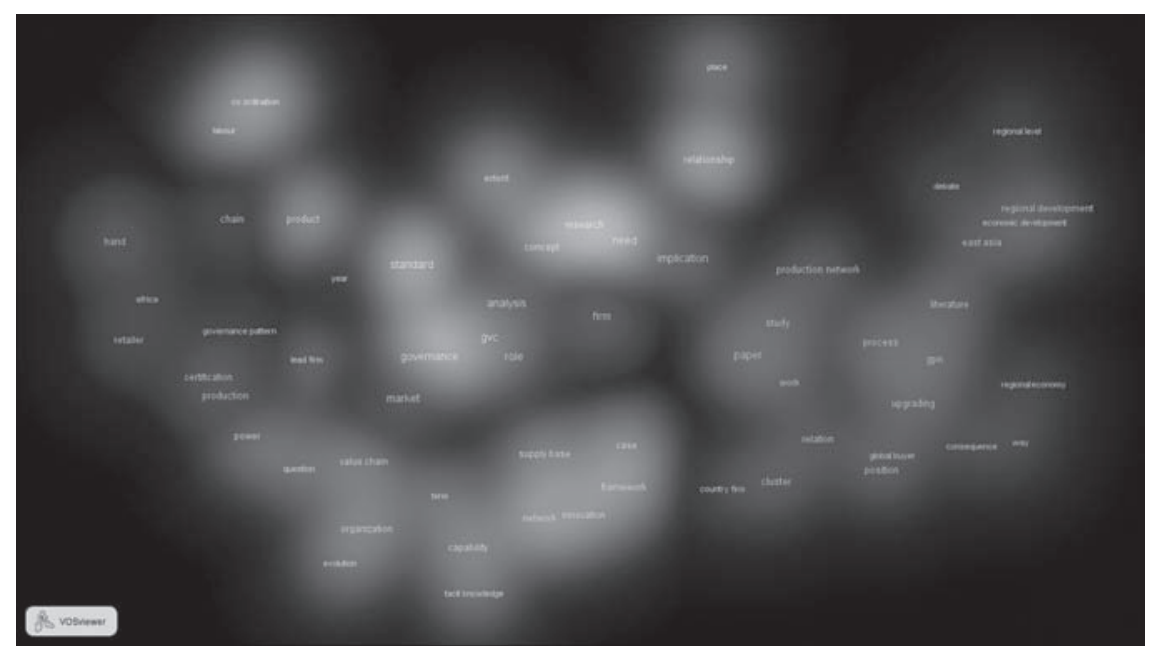

Figure 3.6 Cluster-density view of 20 most cited GVC/GPN papers (themes)

Note: The brightest areas on the figure are the 'hot' zones where terms occur most frequently. 
at the 20 most used GVC/GPN papers and the themes that come out of them, so categorising the themes more widely and identifying those themes that are not necessarily directly linked to the issues we normally deal with in IB. So if we look at that, it is mostly to do with economic and social upgrading. I would like to point out the Giuliani paper in 2005 (Giuliani, Pietrobelli and Rabellotti 2005), for instance, an interesting paper that helps us to theorise around the notion of upgrading, which is something that was certainly alien, previously, to the IB literature. Supplier compliance - this is around standards and how suppliers are compliant with the ethical or production processes as scheduled by key lead firms. Issues of distributive outcomes, impacts: we are, in IB, less concerned with other distributional outcomes than with the performance outcomes for the key actor, the lead actor. So, as a function of this, there is more concern with impact and distributive outcomes in the GVC/GPN literature. There are also issues of poverty, asymmetry, some things which in the context of IB are lesser concerns, to date anyway. Issues of vulnerability, smaller suppliers who are at a power asymmetry disadvantage. A number of people in economic geography and economic development address issues of small suppliers and their marginalisation, labour skills development, sustainability issues, value capture at the periphery.

These are the kinds of themes, when looking very broadly into the most widely cited works, that I believe could be triggers for conversations around whether there is room for IB scholars to, kind of, get a bit out of the box of the firm focus and outcomes, which I believe would be very beneficial. I have to say, however, that there are of course many limitations to my work so far, as well. I didn't look at book chapters at all. I took this first step, which is just to look at papers mentioning GVC or GPN in the title, keywords or abstract. So there may be significant work which is basically not using those terms in the title but do cover these ideas in the body of the work. There is more work that I have to do in terms of fruitfully connecting IB writing with the work of the GVC/GPN literature. Mo Yamin has made a significant contribution in this respect (Yamin 2011). The next steps will entail going back over some of the IB literature and categorising the keywords in context ('KWIC' analysis). This is to say, in which contexts do specific citations take place? What are the implications that IB scholars are drawing from adopting specific literature? So, in a nut shell, this is a preview of what I believe could be a fruitful agenda, drawing on evidence of what has been published so far. Looking at different use of the terminology of GVC and GPN in IB and looking at ways in which the adoption of some of these concepts and their consequences can potentially invigorate new research avenues.

\section{Commodity chains and commodity frontiers: ecology and the state in natural resource industries, by Liam Campling}

Good morning all, and thanks again to Jennifer and Gary for the invite. I teach international business at the School of Business and Management at 
Queen Mary, but I also publish in economic geography journals and have been working for some years on the global value chain/global commodity chain/ global production network frameworks, what I call a political economy variant of 'commodity studies' (Bernstein and Campling 2006). All of them, broadly, have a similar concern, although there are debates around the particularities and the ways in analytically, and so on. So, this all comes together under the idea of commodity chains, but that is just shorthand to capture this entire range of material. I want to talk to the theme of spatial/historical development of multinational enterprises. But I am not going to talk about specific firms. The case that I am going to be talking about is the global tuna industry. Here you have fairly major players like Mitsubishi, Heinz, Lehman Brothers, and private equity involved. There are lots of big players, but they are going to be in the background for the discussion here because instead I want to talk about some steps to try to understand the natural resource industries - in particular the role of multinational enterprises and their attempts to coordinate and control natural resource value chains, which of course, incorporates almost everything around us in the end. This is a little bit theoretical to start with. What I am trying to do here is synthesise the literature on 'commodity studies' (GVC, GPN, and so on), with a framework called the 'commodity frontier'. This is trying to bring in a more political ecology angle, which is another major concern of geography.

The first step is that I'm going to talk through this theoretically, and then I am going to illustrate it through the particular case of tuna. The first step is to identify the particular characteristics of any natural resource which are constituted through the biological and geophysical specificities of that resource, in concert with the social priorities of any commodity sector at any particular moment in time. So, in other words, natural resources aren't natural, naturally resources as they depend on the social and cultural context, effective demand, appropriate technology and different priorities in political choice. So, for example, the insuring of property rights over particular areas at a particular moment in time reflects different priorities of political choice. We can all think about the sub-soil but also the oceans, forests, and so on. So that is the first step.

The second step is the question of distance and durability. Any industry involved in extracting any natural resource or producing natural resources, including agriculture, faces the problem of how to synthesise the organic, and of course, this is a fundamental problem and a historical problem. Enterprises are attempting to overcome, and profit from, the tension between the organic - so organic matter deteriorates, it is perishable - and the synthetic; they are engaging directly in attempting to transform organic matter and face the risk therefore of its deteriorating before final exchange. This is a fairly obvious point but is a starting point to think through more carefully about how these factors influence foreign direct investment decisions, 
the location of investment, and so on. So the point I am trying to focus on in terms of historical change over time is that enterprises deploy a range of business strategies and technological innovations to partially synthesise the organic, to maximise the potential for profitable accumulation. Again, this is fairly obvious and nothing revelatory.

The next step is slightly more of a jump. This is using a guy called Jason Moore (2010a; 2010b) who works on theorising the history of capitalism and is very grounded in lots of the literatures we are talking about today. He tries to see capitalism as an ecological regime that reproduces itself through new commodity frontiers rather than more commonly deployed notions of a 'resource' frontier in which economic activity simply impacts on nature. So what he is trying to argue is that we have to see the development of human society in concert with the development or our interactions with the natural world. In other words, we don't impact on nature; we function through it. He wants to see a more dialectical relationship ... a more dialectical understanding of the relationship between human society and the natural world.

Enterprises engaged in the movement into new commodity frontiers - new forests, new arable land, new fisheries, and so on - have enhanced the possibilities for accumulation because they are entering zones of minimal or zero commodification at first. So this is a commodity widening strategy or a strategy of extensive development, geographically extensive development. This connects time and space. This offers the possibility, for a certain period of time at least, for a high ecological surplus. You can think of this in relation to ground rent and natural resource rents, if you prefer, but of course over time the underlying socio-ecological conditions of the reproduction of this system stagnate or they decline, and production costs tend to converge. So you lose out on the high ecological surplus the initial very high natural resource rent. A typical response - coming back to the point about distance and durability - is sociotechnological innovations, capitalisation, to engage in commodity deepening strategies. So we can think of ever-deeper mines, increased intensification of agriculture, and so on, to try and extract ever more through capitalisation and socio-technological innovation and to appropriate nature from existing commodity frontiers. The way to think of this, in short, is the geographical extent and productive intensity of natural resource industries. This connects back to the first point on property rights which is that, of course, this isn't done in a frictionless environment. It depends entirely on the relationship of access and how you access the natural resources themselves. Because natural resources are very often found, at least in the contemporary context, in biologically or geophysically specific geographical ranges, and very often in the developing world, or Global South, foreign direct investment in natural resource industries often takes place in areas that are more difficult to invest in. Now, this often means that the extent of multinational enterprise territorial embeddedness becomes more deeply rooted because of the necessity of engaging in 


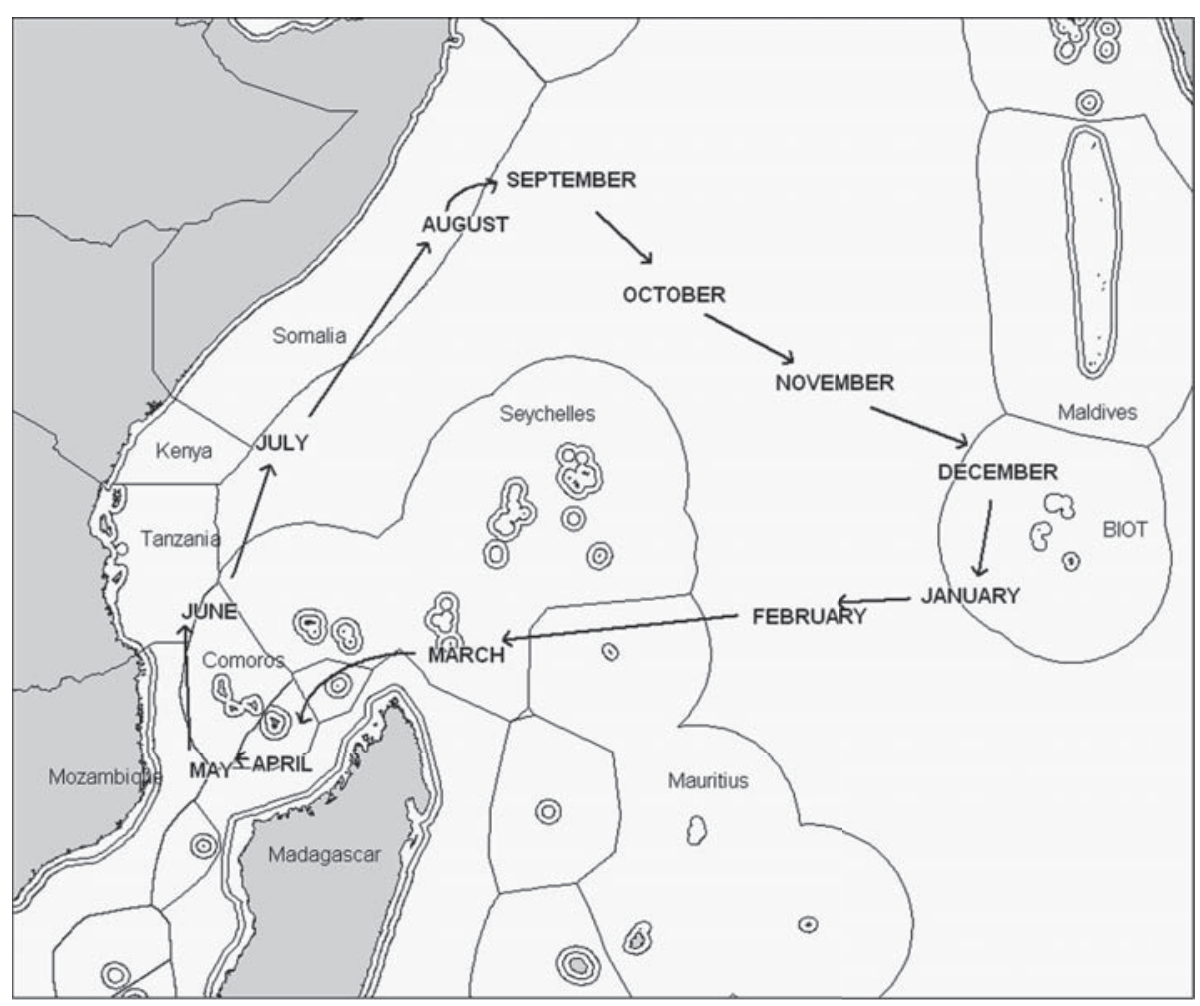

Figure 3.7 Schematic of the migratory flows of tuna Source: Campling (2012).

a relationship with the state. For example, a concession arrangement with a government to establish a plantation, access rights to the sub-soil for mining or access rights in a fishery which is state property very often. So access to natural resources by multinational enterprises is politically contingent upon historical time and geographical space. In other words, different states demand different conditions of access at different times.

That is my opening gambit, and hopefully I am going to show how this works with one particular case which I have been working on for the last ten years, which is the global tuna industry. I am sure that while I am doing so we can recognise how this would connect to other natural resource sectors. The first thing when looking at the biological and geographical, geophysical characteristics of the resource itself, we can see the migration flows of tuna in the Western Indian Ocean (Figure 3.7).

They traverse millions of miles, cutting across all different kinds of state territories. You can see the outer lines here (Figure 3.7), these are the limits of exclusive economic zones - I'll come back to this later on. Another thing to note 
is the huge distances the tuna are travelling - their population movements. In the past, this created an industrial limit to extraction, previous to industrial fisheries. The other thing to note is the Seychelles, where I lived for three years and where I got into tuna in the first place, because the island is dependent on tuna and tourism. The key thing here from a business strategy perspective is that boats use the Seychelles as their home port in order to maximise their day's fishing, so they are following the fish around and minimise their day's 'steaming' - going to and from the fishing zone to offload. So you have a spatialtemporal fix by using the specific place of the Seychelles as the base for the operations themselves. The other thing to note is the different species of tuna. For example, we have the Skipjack which is what Northern Europeans eat in the cans, and the Yellowfin which is generally eaten in Southern Europe - Spain and Italy. Big industrial vessels are used to scoop these fish from the sea - damaging their flesh, but this deterioration in quality doesn't matter because they are put in a can. But if we take a different species like Bluefin, which you have all probably heard of in relation to Japan and sashimi, here each fish is caught with an individual hook, and great care is taken with the fish post-harvest and buyers select individual fish - one fish sometimes sells for a million dollars. Putting a price on the fish is connected to cultures of consumption, but it is also about the biology of the species. For Bluefin, you have an incredibly highly priced species, which can be understood in part by the biological characteristics of the resource itself. Skipjack reproduce very quickly (after 1.5 years), they are constantly reproducing all year round, and they grow to quite a small size whereas Bluefin, which are even bigger than I am, reproduce for only a few months of the year, and it takes them up to eight years to reach sexual maturity. So species differentiation plays a massive role in understanding the strategies of businesses engaged in the particular commodity chains.

Now, on making the organic synthetic, this fairly abstract point that I was trying to make earlier, it is a simple point of canning a fish. The technology was developed by a commission by Napoleon during the Napoleonic Wars, the intellectual property for which was then stolen by a British firm to develop canning as a mass commodity. The other thing that is connected is that before the rise of freezer technology, boats had to offload their catch quickly. For the first canned tuna fisheries around the Bay of Biscay, there would be lots of little canneries dotted around all the coastline of France and Spain and Portugal and the boats would have to go back constantly to these small little canneries because they couldn't freeze the fish. So they would follow the fish around the coast when it was migrating, catch it, bring it back, catch it, bring it back. As a result, the economic geography of the production system until the 1950s was that these tiny little canneries dotted around the coastline which creates massive limitations on the economies of scale in the plants, and so on. With the advent of freezer technology, cold stores and especially recently the 
use of freezer containers, it doesn't matter where you are for processing. The largest processor, which owns the brand John West, is in Thailand. Thailand doesn't have any tuna fisheries of any significance near its coastline. So the role of freezer technology played a fundamental role in the shaping of the international division of labour in this commodity chain.

The other point, more outside of economic geography and international business, is the notion of capitalism as an ecological regime. I mentioned about the commodity widening strategy, and in tuna fisheries you can observe this with the geographical expansion and intensification of catch in the 1970s onwards around Central America and West Africa. Over time these areas became less productive as the initial ecological surplus declines, so you then see the expansion further out, to the Western Indian Ocean and Western and Central Pacific in the 1980s onwards. The commodity frontier is simultaneously widening but also deepening with the introduction of more effective techniques of extraction. Now the geographical expansion has reached across the entire latitude of the fish population movement.

To illustrate the notion of high ecological surplus: for the Yellowfin stocks in the Western Indian Ocean we can see the point in the late 1980s when the catch of Yellowfin declined relative to the catch of Skipjack. So, in other words, the population of the longer living fish that was there began to decline. In order to catch the same number of fish, the boats had to engage in more extensive methods of extraction. An obvious way of understanding a commodity deepening strategy is a shift in basic technology, from pole and line boats, which is what supermarkets like Waitrose and Sainsburys are pitching their sustainability criteria around today, to enormous purse seine boats which catch a whole shoal of fish in one go. So these bigger boats are able to extract more and more resource. They also use a thing called fish aggregating devises, which is a big thing in the UK environmental movement recently, where all the fish aggregate under a floating object, it uses sonar to tell the captain where the fish are. It is the intensification of the technology involved in trying to extract ever more from this resource.

Finally, I want to talk briefly about the question of property. It is a summary of work by a guy called C. B. MacPherson (1983) around property. He conceptualises property as a bundle of rights implemented and conferred by social relations and reflected in juridical practices, which of course change over time. This depends upon political context, and so on. The main thing to talk about in the oceans is that there is a doctrine of the freedom of the seas developed by Hugo Grotius in the $16^{\text {th }}$ century. It was only in the 1980 s that you really see the institutionalisation of property in the sea. You had the largest enclosure in human history in the 1980s when the United Nations declared, or UN members, declared the creation of exclusive economic zones. These introduced a new political struggle between coastal states, very often developing coastal 
states, and multinational enterprises including firms like Mitsubishi, Heinz, and so on. You can see here where the exclusive economic zones are. The way I am conceptualising these are as state property (Campling and Havice 2014). You can see the expansion of the world: suddenly overnight it became the property of particular states. So the question here is, how do you access it as a foreign fishing fleet? This is the debate around the competition between states and firms and around access to natural resources. The Pacific Islands' exclusive economic zones are grouped together which allows them to engage in a form of South-South cooperation where they collectively bargain with foreign fleets. This deepens the politicisation of accessing the resource. This is a particular story because the fish happen to flow through all these exclusive economic zones, and if you want to get access to fish anywhere, commercially, profitably, then you have to be able to follow the fish. So you have to engage in direct negotiation with this collectivity of states.

So to conclude, what I am trying to argue for here is to understand the role of multinational enterprise strategy in the context of relationships between nature and states, specifically in relation to the natural resource industries. The idea of a commodity frontier I hope helps to introduce a way of thinking through how these strategies develop over time, both intensive and extensive development. The big weakness in this approach so far, which is where I draw on international business literature, is to look at the specific firm-level strategies, the differential strategies of firms, in this sector. It is worth emphasising that the competitive conditions that create the intense race to fish are undermining the very conditions for this competition to exist. In other words, firms are fishing out the fish. Partly, this can be explained through the need for firms to intensify their extraction.

\section{Review and discussion by Peter Buckley}

Thank you. When I was asked to do this, I said I would play the role of 'sweeper' on the Kaiser Franz Beckenbauer model of picking up everything that is neglected by everyone else. But, in fact, I think this boils down to three sets of comments. The first set of comments is about the concepts that cut across international business and economic geography, which I think we have heard quite a bit about. Second, is the focus on global value chains and, related to that, the statistical and data issues which I think nobody has mentioned but that I think are incredibly important.

I think the first point is that as we can see, geography is one of the key comparators that we have in international business. We have historical comparisons; we have geographic comparisons. As we have alternative position comparisons, what would have happened if an event hadn't happened? My starting point with geographical elements is that the multinational enterprise is a really good testing point for this because you are holding the firm, the institution, constant 
and looking at different geographical manifestations of that firm. Clearly, we have gone quite a bit further here. I think one of the worries I have, and possibly the only worry I have, about this is that we might get hung up on terminology. I think the concepts that we have in common are strong and powerful and useful. But if we get hung up on whether we call something a global value chain, a global production network, a global commodity chain, I think that will set us back. I use the term 'global factory' (Buckley, 2009, 2011) and this panel that shows that there are three different people using 'global factory' in different ways. Rudolf did an excellent job there of showing, actually showing, some of the possible dangers of this, that it is not just about using those terms.

If we get hung up on terms and we worry too much about terms, it might detract from something that could be really intellectually important. This is that a whole set of groups of academics are working on very similar projects, and we have a lot to learn from each other. One of the 'buzz phrases' I use is that multinationals are increasingly internalising knowledge and externalising operations. If you think about a lot of what was said, that fits right across the board of all these concepts that we are using. The greater international division of labour, the finer and finer breakdown of international division labour. These are concepts that have a lot of life in them and are looked at from different angles. It is interesting when you use the term 'black box' your black boxes might be different from my black boxes. Your black box might be the multinational enterprise; my black box might be the geographical and environmental surroundings of it. That is very encouraging because we can put our black boxes together and hopefully make transparent boxes. I do think there are massive opportunities here. I think the other thing, we have been doing work on regional cities in China and looking at both place and space which is a paper we have given at this conference highlights. One of the things that economic geography has highlighted is a phrase that I think Martin used which is the assumption of 'methodological nationalism'. I think this is gradually breaking down in international business. We tended to think of the nation, we tended to think of FDI, going from country A to country B and now we really need to think of it as going from different places and spaces. There are loads of really interesting issues. My only concern is that the danger of this is that we get stuck on the terminology and that we forget the underlying concepts. I think this is really potentially really exciting.

The central issue is global value chains and how we conceive of that, and, again, we have the role of how far the creation and power of multinational enterprises running these is, and how far its external factors are. What are the geographical and locational factors, and how do we put that together? The way we conceive of that, I think, we are going to have to have debates about how best to conceive of this and how best to put the role of the multinational enterprise into this.

That leads to the third thing, which hasn't been mentioned, which is when we start to look at this, the statistics that we have are incredibly inadequate. 
Statistics are either based on national trade flows, based on industries, which is a really dated concept because all global value chains, all global factories, go across conventional industries. The good news is that the people who work on this and put the statistics together and produce things like the World Investment Report are very aware of this. When I was principle consultant for the World Investment Report in 2011, we looked at non-equity modes, and that was the first time that the United Nations Conference on Trade and Development (UNCTAD) had got away from its fixation on FDI. Now as we all know, FDI is one way of doing international business. It is an iconic way, and in many senses it may be the most important way: it conveys control, blah, blah, blah. But non-equity modes are very important in global value chains. I think the 2011 World Investment Report (UNCTAD, 2011) was the start of UNCTAD looking more at what they are set up to do, which is transnational corporations, all the activities of transnational firms. That I think was a start. Now they are starting to look at value-added trade. This isn't going to go in the final report, but there is an incredible competition among international institutions to be the first to produce statistics that we can all really use. I was at Organisation for Economic Co-operation and Development (OECD) a couple of weeks ago in Paris, which it was one of the best days I've had. They were all statisticians and it was fantastic because they are really trying to get a handle on what is really happening in the world economy.

What is really happening in the world economy is not encapsulated by national income statistics. It is not encapsulated by industry-level statistics. It is encapsulated by dynamic changes in global value chains and all the ramifications that has for where activity takes place, who owns it, who appropriates the benefits from it, and so on. So I think that not only are we at a really exciting time with regard to the concepts; we are also at a really exciting time in terms of policy and measurement because if we can get proper measurement in this, then policies can become a lot more rational. Instead of countries going out and saying they want to attract more FDI, and it doesn't matter what it is, let's just get more in, we can be much more nuanced about exactly what type of FDI individual countries are more able to attract and get more benefit from. So, in a sense, watch this space for OECD, UNCTAD and the rest who are desperately trying to get value-added trade and then move on to ways we can get a handle on global value chains. I think this is a really worthwhile operation, and I think it might be the start of something big.

\section{Questions}

Question 1, Jean-Francois Hennart: Martin, if we look at the data you showed us on Apple, when we consider this, how does this impact on trade statistics? Because in terms of trade statistics, the full value of the Apple product, if it is 
a Chinese export... when in fact the value added is miniscule. We have people talking about bi-lateral trade balances...

Martin Hess: That is a major issue, and Apple produces all of its iPads, iPhones, etc. in China. This distorts the China/US trade balance because the value added in China is the labour cost within the Foxconn factories plus some other stuff that is produced in China by other multinationals in terms of components. It is compared to the sales price and the import price. Yes, it is minuscule. I think there is a reaction on the political side now, and Peter alluded to that in the context of the OECD about trade organisations trying to find new ways to get to terms with the value added and measuring global value chains. They have produced a recent report, a literature review on value chains on GPNs by the WTO and the Li and Fung Institute of all places (Elms \& Low, 2013). They are critically aware of these issues, and for the US it is a massive debate about trade imbalances and what they reflect and what they hide. If you took this into consideration the trade data for the US/China would be very different.

Jean-Francois Hennart: And by the way, there is the equivalent when you look at this global value chain and products with value added being in one place and financial flows in terms of export and import being very different from the value added. You have the same thing in terms of financial flows because through tax havens basically what you have is a geography of accumulation of profits which is quite different from the physical value added of multinationals, which makes FDI data useless. We have the same problem in terms of the geography of profit accumulation versus the geography of profit generation. For example, the Netherlands, which is for everything but a name, a tax haven, you have got ... and if you look at the profitability of multinationals in the US since most of the profits aren't declared in the US, because they are kept in offshore locations, this affects all the literature about multinationals and their performance because their reported profits aren't necessarily where the profits are. So there are tremendous issues.

Peter Buckley: The statisticians are on to that. One of the things that the OECD was talking about was looking at pass-through foreign investment where an American company invests in the Netherlands but the intention is to go somewhere else. They are working on techniques with tax authorities and others to be able to do that. This means that in a few years we could have a revolution in terms of the statistics that we are dealing with. It could be much more accurate, and then with the value-added trade I think there is a table in a recent World Investment Report (2013: Figure IV:32). Singapore is a classic one where it is an entrepôt, so you take the exports minus the imports and the value-added element is much smaller than the massive trade. It is a massive trading location, but not a massive value-added location. So I think there is awareness of these 
issues. I think that is to the credit of us as a community who have started to show that what we are working with are really very imperfect data to measure what is really going on in the world economy.

Question 2, Mohammad Yamin: I think this critical notion of methodological nationalism, it is mistaken. I would like to reflect on that. I think that the role of the state deserves more specific attention, and it doesn't seem to get that. I think the issues that Jean-Francois referred to about transfer pricing and tax havens means that regulation is very important. One of the issues that bothers me, and I don't know the solution, is really economic development is a national issue, fundamentally. Not exclusively, but I think fundamentally it is the role of the state. In emerging markets especially, if you ignore the role of the state, you misunderstand what is happening. When we look at global factories or global value chains, I think this notion of the nation state is under represented. I understand why, but I have issues with it.

Martin Hess: Can I answer that? Thanks, Mo. You are addressing an important point and there are recent papers, one just out by Adrian Smith (Smith, 2014) and another one in the pipeline by others, conceptualising the state with a GPN/global value chains framework because it has been neglected to some extent. Arguably, it has been seen in international business and much of economic geography as something external to all these value creation processes. I think it is important to recognise the state and the various roles the state has, and often contradictory roles. It's not just a regulator; the state is also a massive buyer. If you think of the emergence of companies like Samsung in South Korea that was much to do with military spending by the US, conflicts in Asia, the Cold War. The state is a massive buyer. The National Health Service (NHS) buys clothes to the tune of goodness knows how many billion pounds over the years. The state is a facilitator in terms of trade negotiations. Often it is a producer. We still have an incredibly large number of state-owned multinationals, part or fully state-owned in various parts of the world, even under neo-liberalism. The second issue that you raised about the importance of the nation-state and the scale of the nation-state as opposed to other scales like the local, again I agree we mustn't neglect it, but it must not be the single focus of our attention. Development within a nation-state is again contested. The state has a dual role: it is a supporter of accumulation of capital; at the same time, the state should implement and enforce labour laws, etc. Again, going back to the garment industry, countries like Bangladesh or Cambodia, at the same time they want to keep and maintain FDI by Korean garment multinationals and neglect labour rights to some extent to keep them happy; at the same time, they have a developmental role to play in securing labour rights and working conditions. So it is contradictory. You also have the politics of accumulation. In the UK we talk about the North-South divide - there was 
this BBC documentary 'Mind the Gap'. Often state policies focus on developing particular clusters, whether it is London or Silicon Valley. Again, Silicon Valley also came out of military spending and government activities. The role of the state is clearly crucial. The nation-state as an arena of political activity is still important, but not at the expense of other scales, be they supranational or below the nation-state level. That is what I would argue.

Peter Buckley: I agree Mo, I think that is possibly something that has been neglected. I saw some figures recently that were really surprising about the size of the Chinese state. It is tiny. The Chinese state bodies are a fraction of government bodies in Western Europe as a proportion of the population, and by proportion of other things. That is really an interesting take on Chinese development, the unregulated nature of Chinese development. I think you are right, and the point is well taken.

Liam Campling: I would agree as well. That is what I was trying to do in my presentation. If you look at the national oil companies, they are emerging as major players, either as resource-seeking national oil companies or more national developmental oil companies using their own state property as it were. There is a dual model that is displacing the old oil majors and transforming the global oil economy.

Peter Buckley: I think the straw man that is being broken down is taking the nation as a homogenous thing. So, having moved away from that and saying it is much more differentiated by province, by city, particularly by city. Perhaps we have lost something in that.

Question 3, Jennifer Johns: I would like to ask a question about the use of these concepts and frameworks in relation to impact. Do we as a community have a sense of the degree to which these frameworks, such as GVC and GPN are understood by firms themselves? Is there a feedback mechanism in the sense that our concepts are impacting the empirics we seek to understand?

Peter Buckley: Yes. One of our impact studies was on the work we have been doing on regional cities in China. We did that for the UKTI (UK Trade and Investment) with CBBC (China-Britain Business Council) and how they used that as a locational choice for deciding exactly which city to locate in China. That is interesting because it is very much theory driven. The decision about where to put the most recent British Consulate was based on our model. I think they had their answer beforehand, but the model justified it, so next time you are in the British Consulate in Wuhan, you know why it is there!

Liam Campling: In my own work I use a global value chain analysis to understand the industrial structure and trade regimes, and that work has fed directly into developing country government policy on trade negotiation and 
outcomes. This had the result of creating a new trade rule, which provided a condition for considerable foreign investment in isolated places like Papua New Guinea. I think that it is useful and can be deployed very practically as well as theoretically. I think that is why it has been taken up so much by the World Bank, and so on. If you do the same exercise as Rudolf did for policy documents, what you see is a massive explosion around 2010 when the World Bank, ILO and other big international agencies, UNCTAD, etc., are using the global value chain framework precisely because it can be deployed in a very practical way to understand how industry works beyond the nation-state. The downside, which is where I think Peter is right to say that we need to avoid a semantic debate around whether you use the GVC/GPN/GCC frameworks the one thing that is important is the substantive debates across the literatures, within GVC or within GPN, and there is no agreement. For example, one of the biggest areas where there is contestation is around the question of whether we are using the framework as a policy mechanism or as a tool of analysis. Are we trying to design global value chains, or are we trying to understand how they work? That is a major area of debate.

Peter Buckley: I think there are also some unanswered questions. I say unanswered because I don't have the answer - which is the role of the satellite firms in the constellation of the global factory. OK, we know a lot about the strategy of the focal firm. But what about the strategies of all the companies that are linked in? And, if all that is true, can we really talk about the strategy of the global factory? We can talk about the strategy of the focal firm, but is that subsuming? Are we subsuming all the suppliers and customers, technology suppliers, alliance partners, etc. into one thing? How far can you do that? I don't have the answer to that. That is a really interesting area of research: to look at how far you can do that and how far the strategies of the individual firms work out. There is stuff being done on that now that looks interesting.

Question 4, Mohammad Yamin: Just on that point, I have just been reading a few papers and the message I got was that global value chains are actually restructuring, in some sectors anyway, and the restructuring is mostly in terms of consolidation. The number of suppliers is significantly less by factors of more than a hundred. That would speak to the fact that the strategy of the core firm is important as it is more concentrated. I know that it is a semantic issue, but geographically a lot of these suppliers are in China, in South East Asia, and we talk about global value chains. So in that sense they aren't really global - in the literal geographic sense. We shouldn't lose sight of this.

Peter Buckley: Yes, well Alan [Rugman] would talk about regional value chains. 
Liam Campling: There is a neat trick around that, you would say a global value chain for automobiles as a whole and then a 'value chain' for automobiles that was specific to a particular region. That has been widely recognised in the literature as a problem and a trap to avoid. There are quite simple ways around it. Also, Peter Nolan's work on the cascade effect, and Peter Gibbon's on the role of first tier suppliers becoming ever more concentrated, which is what you are talking about. This concentration moving back into first tier suppliers, creating what Nolan calls the 'external firm' - talking about the externalisation of operations - they are externalised but still controlled by the lead firm, and it becomes that the firm is able to shape through procurement the way that the supply chains function.

Peter Buckley: I don't know if it is the same article, but the article I read had exactly the problem you were mentioning. It was almost using the word 'should'. It was saying the focal firm 'should' reduce the number of suppliers, 'should' consolidate. So we have gone towards strategy advice.

Mohammad Yamin: The paper with Gereffi for Review of International Political Economy did say what was happening, not that it should.

Peter Buckley: The one I read almost elided into advice about consolidation.

Question 5, Gary Cook: Going back some years ago to when the research I was doing was going out to talk to oil companies and asking them about their subcontracting relationships. This was at the kind of time when the view of firms was as a nexus of treaties or common practices was popular and there was talk of fuzzy boundaries. What really struck me was that when I talked to those oil executives, they saw the world in a very black and white way. They had no fuzziness at all about what they viewed as being in the firm and what they viewed as being outside the firm. They also had a very clear view about why they used particular kinds of subcontracting relationships with particular types of subcontractors. The methodological point that this gives us is that somewhere along the line, if we are going to understand these value chains, we need so spend some time getting inside the companies' heads if you like and understanding how they view the world because the danger with this is that social scientists can construct a view of what is happening which can be divorced from the way firms see themselves.

Peter Buckley: Yes, I had a similar experience when I was doing work on joint ventures and alliances from actually looking at contracts, which is what Coase recommended that we do. We should look at contracts, not theorise in the abstract.

Liam Campling: Yes, well economic geographers do tend to do applied empirical work. I have interviewed over 700 people in 20 countries and literally followed 
the fish and move away from blueprint theorising which is a real problem across the social sciences.

Jennifer Johns: When I've interviewed firms and explained the conceptual frameworks for projects. I have found that interviewees are often familiar with the notion of value chains, Porterian value chains, but are not aware of more complex concepts. I wonder how far the managers are aware of the interconnection between actors in the GVCs/GPNs and how few people have a genuine strategic overview of the network.

Liam Campling: I suppose it depends how high up you go.

Peter Buckley: I think it just depends on who you talk to. Whether senior managers have the overview is a difficult question.

Jennifer Johns: Yes, well sometimes it can go back to what you were saying yesterday in your keynote speech, Peter, about the power of the individual as well. We are educating some of these managers as well.

Peter Buckley: Indeed. It is rather like the story of the product cycle. It went out of being because we all taught it, and then everyone could anticipate what it was going to happen.

Liam Campling: It also comes to the political power of the corporation; the senior level technocrats in firms are very aware of what is happening in the WTO, lobbying their own governments, for example. Much depends upon whether a firm has more or less political interests. Some firms would benefit more from what some people would call policy rents than others would.

Question 6, Roseline Wanjiru: An observation on global production networks and as they touch down in particular places, I think that the geographical peripheries, those on the extreme margins of the global economy, countries such as those in sub-Saharan Africa, for example, where a lot of debate around lead firms and a lot of the theories that we present are based on particular assumptions. Possibly because there is a lack of information. One of the challenges of doing research on the margins is the lack of official, or reliable, empirical data on which to publish. The realities of global business are that these firms have real impacts on people, on families, on societies, so it is a limitation of the method that the literature is interesting and the theories are relevant, but if you look at some contexts where there is either no data or few researchers working, you have major challenges trying to get into the debate or show why that particular context is different. I see that we are giving firms privilege that comes from a Western context. I am trying to say that there is a world beyond what is reported in the articles. 
Rolf Sinkovics: From my perspective, I think that there is some value in conceptualising academia as a global production network in itself. There are various actors producing work, and we are all driven towards some types of outputs. This is something that has quite significant implications now. PhD students are encouraged now, well no, they are required, to work towards their PhD within three years. That funnels the whole process towards something that is much more readily available. We have heard today about statistical challenges that need to be dealt with senior individuals in supra-regional organisations. We are not yet there that we cannot guide our students to doing research on the margins very frequently - because that will not produce the tangible output that is required by the PhD student and for the supervisor to report back that their through-put rate is appropriate. When we conceptualise what is happening in academia, we are seeing that we talk about outputs. There is some value in going through concepts, but when we review them, we will see that there are also some unique concepts that we are also ignoring. Some in economic geography and developmental literature have not resounded well in the international business literature for exactly these particular reasons, because they are more cumbersome.

Liam Campling: On Roseline's question I would look at the literature in development studies and development geography. People have been grappling with the problems you are talking about there since the 1960s. There are huge literatures on the relationship between multinationals and places in the periphery. But still, often the data aren't there for specific issues. For example, I was in Madagascar in December working on a particular value chain. There is no data. My research is all based on interviews. You are lucky to get bits and pieces of data here and there. Otherwise you rely on interviews. Talking of PhD students (Rudolf's point), I have one working on the global value chains of iron and rubber in Liberia, and another on e-waste in Malaysia. They are all based on the combination of descriptive statistics and very substantial semi-structured interviews. So I think it is possible in the timeframe.

Martin Hess: I would agree. Formal data is hard to come by for places on the periphery. There is a growing body of work done on GVC and GPN analysis of subSaharan Africa and elsewhere. It also includes research by people from these parts of the world, not just us parachuting in from the West and spreading the message of integrating into value chains. More nuanced analyses are on their way, which is encouraging.

Peter Buckley: What is important is to put it in a concrete and delimited context - to try to look at everything is difficult. To focus on one particular country, on one particular area, then you have a real chance of making a contribution. 


\section{Summary}

This chapter has presented a record of the panel session aiming to illuminate and interrogate the shared - and occasionally divergent - perspectives on the spatial and historical development of MNEs by international business and economic geography. It is clear from this panel session that many of the key questions posed by each discipline in this specialist area are shared. However, each discipline has developed different (but not necessarily uncomplimentary) frameworks for collecting and analysing data on global sourcing and firm activities in general. The panel session revealed that there is much interest in, and excitement around, increased interaction between the two disciplines. Several barriers to greater communication - such as issues around the labelling of terms and frameworks, the low degree of cross-referencing between the two disciplines in this field and the availability and applicability of data - were identified by panellists and discussants. These barriers were not considered to be insurmountable, and the panel session highlighted a possibility of future fruitful collaboration with an aim to increasing our understandings of the spatial and historical evolution of MNEs and current change dynamics in the global economic environment.

\section{References}

Altenburg, T., Schmitz, H. \& Stamm, A. (2008) 'Breakthrough China's and India's Transition from Production to Innovation'. World Development, 36(2)' 325-344

Barrientos, S., Dolan, C. \& Tallontire, A. (2003) 'A Gendered Value Chain Approach to Codes of Conduct in African Horticulture'. World Development, 31 (9), 1511-1526.

Bernstein, Henry and Liam Campling (2006) 'Commodity Studies and Commodity Fetishism I: Trading Down'. Journal of Agrarian Change, 6(2), 239-264

Beugelsdijk, S. and Mudambi, R. (2013) 'MNEs as border-crossing multi-location enterprises: The role of discontinuities in geographic space'. Journal of International Business Studies, 44(5), 413-426

Beugelsdijk, S., Mudambi, R. \& Andersson, U. (2013) 'Special Issue: The Multinational in Geographic Space'. Journal of International Business Studies, 44(5), 413-544.

Buckley, P. J. (2009) 'The impact of the global factory on economic development'. Journal of World Business, 44(2), 131-143.

Buckley, P. J. (2011) 'International integration and coordination in the global factory'. Management International Review 51(2), 269-283.

Campling, Liam (2012) “The Tuna 'Commodity Frontier": Business Strategies and Environment in the Industrial Tuna Fisheries of the Western Indian Ocean'. Journal of Agrarian Change, 12(2-3), 252-278

Campling, Liam and Elizabeth Havice (2014) 'The problem of property in industrial fisheries'. Journal of Peasant Studies, 41, 1-21.

Coe, N.M., Hess, M., Yeung, H. W-C., Dicken, P \& Hess, M. (2004) “"Globalizing” regional development: a global productions network perspective'. Transactions of the Institute of British Geographers, 29, 468-484. 
Coe, N. \& Hess, M. (2005) 'The Internationalization of Retailing: Implications for Supply Network Restructuring in East Asia and Eastern Europe'. Journal of Economic Geography, 5(4), 449-473.

Dolan C. \& Humphrey J. (2004) 'Changing governance patterns in the trade in fresh vegetables between Africa and the United Kingdom'. Environment and Planning A, 36(3), $491-509$

Elms, D. K. \& Low, P. (2013) Global value chains in a changing world. Geneva: World Trade Organization.

Ernst, D. \& Kim, L. (2002) 'Global production networks, knowledge diffusion and local capabilities formation'. Research Policy, 31, 1417-1429.

Froud, J., Johal, S., Leaver, A. \& Williams, K. (2012) 'Apple business model: Financialisation across the Pacific'. University of Manchester: CRESC Working Paper 111. Available from: http://www.cresc.ac.uk/publications/apple-business-model-financializationacross-the-pacific

Gereffi, G., Humphrey, J. \& Sturgeon, T. (2005) 'The governance of global value chains'. Review of International Political Economy, 12(1), 78-104.

Giuliani, E., Pietrobelli, C. \& Rabellotti, R. (2005) 'Upgrading in Global Value Chains: Lessons from Latin American Clusters'. World Development, 33(4), 549-573

Hassink, R. (2005) 'How to Unlock Regional Economies from Path Dependency? From Learning Region to Learning Cluster'. European Planning Studies, 13, 521-535.

Henderson, J., Dicken, P., Hess, M., Coe, N. \& Yeung, H. W-C. (2002) ‘Global Production Networks and an analysis of economic development'. Review of International Political Economy, 9(3), 436-464.

Hess, M. (2004) 'Spatial Relationships? Towards a reconceptualization of embeddedness'. Progress in Human Geography, 28(2),165-186.

Humphrey, J. \& Schmitz, H. (2001) 'Governance in Global Value Chains'. IDS Bulletin, 32(3), 19-29.

Humphrey J. \& Schmitz H. (2002) 'How does insertion in global value chains affect upgrading in industrial clusters?'. Regional Studies, 36, 1017-1027.

Klooster, D. (2005) 'Environmental certification of forests: the evolution of environmental governance in a commodity network'. Journal of Rural Studies, 21, 403-417.

Kogut, B. (1985) 'Designing Global Strategies: Comparative and Competitive Valueadded Chains'. Sloan Management Review, 26, 15-28.

MacPherson, C. B. (1983) Burke. Oxford: Oxford University Press.

Moore, J.W. (2010a) “'Amsterdam is Standing on Norway" Part I: The Alchemy of Capital, Empire and Nature in the Diaspora of Silver, 1545-1648'. Journal of Agrarian Change, 10(1), 33-68.

Moore, J.W. (2010b) “Amsterdam is Standing on Norway" Part II: The Global North Atlantic in the Ecological Revolution of the Long Seventeenth Century'. Journal of Agrarian Change, 10(2), 188-227.

Mutersbaugh T. (2005) 'Fighting standards with standards: Harmonization, rents, and social accountability in certified agrofood networks'. Environment and Planning A, 37(11), 2033-2051

Nadvi, K. (2008) 'Global standards, global governance and the organization of global value chains'. Journal of Economic Geography, 8(3), 323-343.

Ponte, S. \& Gibbon, P. (2005) 'Quality Standards, Conventions and the Governance of Global Value Chains'. Economy and Society, 34(1), 1-31.

Raynolds, L. T., Murray, D. \& Heller, A. (2007) 'Regulating Sustainability in the Coffee Sector: A Comparative Analysis of Third-Party Environmental and Social Certification Initiatives'. Agriculture and Human Values, 24(2), 147-163. 
Smith, A. (2014) 'The state, institutional frameworks and the dynamics of capital in global production networks'. Progress in Human Geography. Advanced online access DOI: $10.1177 / 0309132513518292$

Sturgeon, T., van Biesebroeck, J. \& Gereffi, G. (2008) ‘Value chains, networks and clusters: reframing the global automotive industry'. Journal of Economic Geography, 8, 297-321.

UNCTAD (2011) World Investment Report: Non-equity modes of international production and investment. Geneva: United Nations.

UNCTAD (2013) World Investment Report: Global Value Chains, Investment and Trade for Development. Geneva: United Nations.

Yamin, M. (2011) 'A commentary on Peter Buckley's writings on the global factory'. Management International Review, 51, 285-293.

Yeung, H. W-C. (2009) 'Regional development and the competitive dynamics of global production networks: an East Asian perspective'. Regional Studies, 43(3), 325-351. 